\title{
Stanisław Skórka
}

Instytut Nauk o Informacii

Uniwersytet Pedagogiczny w Krakowie

e-mail: skork@@up.krakow.pl

\section{Wizualizacja nawigacii w serwisach typu discovery}

STRESZCZENIE: Zintegrowane systemy biblioteczne nowej generacji, zwane również systemami typu discovery and delivery lub search and discovery, zaliczane są do istotnych innowacji w zakresie techniki wyszukiwania informacji oraz jej prezentowania, m.in. ze względu na poszerzenie zasięgu przeszukiwania o dokumenty elektroniczne udostępniane w bazach danych i repozytoriach cyfrowych. Istotną rolę w ich prawidłowym funkcjonowaniu odgrywają systemy nawigacji ułatwiające użytkownikom odkrywanie drogi do celu.

Przedmiotem artykułu jest analiza porównawcza elementów systemów nawigacji zastosowanych $w$ interfejsach użytkownika systemów bibliotecznych nowej generacji (VuFind, Primo ExLibris, SummonProQuest, Encore InnovativeInterfaces, ProlibIntegro, Virtua/Chamo), a szczególnie wizualizacja ich mechanizmów, służących kierowaniu użytkownika do szukanego dokumentu, a także ułatwiających podejmowanie decyzji o wyborze następnej opcji lub linku.

SŁOWA KLUCzowe: systemy informacyjne, systemy typu discovery, nawigacja, prezentacja systemów nawigacji.

\section{Wizualizacja jako wyzwanie dla projektantów}

Dostępujący rozwój technologii informacyjnych, w tym m.in. technologii mobilnych, wpływa nie tylko na szybkość i dostępność informacji, ale 
również na rozwój technik i sposobów jej prezentacji. Wizualizacja informacji polega na wykorzystaniu interaktywnych wizualnych reprezentacji danych abstrakcyjnych w celu wzmocnienia poznania ${ }^{1}$. Jest procesem reprezentowania danych w sposób wizualny i sensowny, dzięki czemu użytkownik może je lepiej zrozumieć ${ }^{2}$. Wizualizacja (czy też wyświetlanie lub prezentowanie) informacji związana jest m.in. z dziedziną projektowania informacji ze względu na estetyczny walor komunikatu, nadawany w procesie projektowania layoutu oraz graficznej warstwy interfejsu. Celem autora niniejszego artykułu było zestawienie i porównanie sposobów prezentacji elementów funkcji nawigacyjnych w systemach wyszukiwania lub katalogach tzw. następnej generacji (ang. next-generation online catalog).

\section{Pojęcia}

W literaturze przedmiotu zauważa się podział systemów wyszukiwania nowej generacji na discovery interfaces ${ }^{3}$ (interfejsy odkrywania) oraz discovery services ${ }^{4}$ (usługi odkrywania). Interfejsem odkrywania określa się oprogramowanie instalowane ponad katalogiem oraz istniejącymi bazami danych, tzw. nakładkę (warstwę) obejmującą swym działaniem ich zawartość. Interfejsy odkrywania zastępują dotychczasowe katalogi elektroniczne, przejmują ich zadania, przeszukując zasoby bibliotek, oferując równocześnie szereg nowych funkcji, m.in. nawigację fasetową, możliwość komentowania i oznaczania własnymi słowami kluczowymi książek itp. ${ }^{5}$ Przykładami interfejsów typu discovery są programy: VuFind

${ }^{1}$ C. Ware, Information Visualization. Perception for Design, 2nd Edition, Amsterdam 2004, s. XVII.

2 Information Visualization User Experience (UX) Topic Overview/Definition [online]. The Interaction Design Foundation [dostęp 30 września 2017]. Dostępny w World Wide Web: https://www.interaction-design.org/literature/topics/information-visualization?utm_source=facebook\&utm_medium=sm.

${ }^{3}$ D. Bilal, Library Automation. Core Concepts and Practical System Analysis, Westport 2014, s. 5-7.

${ }^{4}$ Y. Wang \& J. Mi, Searchability and Discoverability of Library Resources. Federated Search and Beyond, „College \& Undergraduate Libraries” 2012, 19: 2-4, s. 236.

${ }^{5}$ D. Bilal, dz. cyt., s. 6. 
(oprogramowanie otwarte), Primo ExLibris, Summon ProQuest, Encore Innovative Interfaces, ProlibIntegro, Virtua/Chamo itp. ${ }^{6}$

Serwis typu discovery jest połączeniem opisanego wcześniej interfejsu odkrywania nowej generacji oraz technologii przetwarzania w chmurze (ang. cloud-based), w którym poszerzono model wyszukiwania federacyjnego o możliwości przeszukiwania wielu rodzajów elektronicznych zasobów, np. e-książek, e-czasopism, repozytoriów, artykułów prasowych itp. ${ }^{7}$ Serwisy discovery ułatwiają dostęp do wielu zasobów w rozmaitych formatach za pomocą jednego wspólnego interfejsu. W ostatnich latach stały się również integralnymi częściami tzw. platform usług bibliotecznych (ang. Library Services Platforms) - zintegrowanych systemów bibliotecznych nowej generacji, jak np. Sierra InnovativeInterfaces, Alma Ex Libris. Przykładowymi serwisami typu discovery są: Primo ExLibris, Summon ProQuest, EBSCO Discovery Service, OCLC WorldCat.

Oprócz wyżej wymienionych pojęć w literaturze przedmiotu spotyka się również termin discovery system (system odkrywania) ${ }^{8}$ oraz narzędzia odkrywania (ang. discoverytools) ${ }^{9}$. Wszystkie wspomniane narzędzia informatyczne mają tzw. funkcjonalności wspierające użytkowników w poszukiwaniu informacji bez konieczności posiadania wiedzy na jej temat. Cechami charakterystycznymi serwisów odkrywania są ponadto:

- przeszukiwanie wielu zasobów jednocześnie, np. katalogu biblioteki, baz danych itp.

- zastosowanie metadanych do indeksowania zasobów,

- udostępnienie użytkownikom opcjonalnego zawężania wyników wyszukiwania wg faset,

- przeszukiwanie różnorodnych typów dokumentów,

- umożliwienie dostępu do pełnych tekstów dokumentów,

- wspieranie modelu odkrywania informacji przez użytkownika.

${ }^{6}$ M. Breeding, The Future of Library Resource Discovery. A White Paper Commissioned by the NISO Discovery to Delivery (D2D) Topic Committee [online]. Baltimore: NISO, 2015, 53 s. [dostęp 30 września 2017]. Dostępny w World Wide Web: http://www.niso.org/ apps/group_public/download.php/14487/future_library_resource_discovery.pdf, s. 3-4.

7 D. Bilal, dz. cyt., s. 7.

8 T Sadeh, From Search to Discovery [online]. IFLA Library [dostęp 30 września 2017]. Dostępny w World Wide Web: http://library.ifla.org/id/eprint/104, s. 1-17.

9 M. A. Hofmann, Sh. Q. Yang, "Discovering" what's Changed. A Revisit of the OPACs of 260 Academic Libraries, „Library Hi Tech” vol. 30: 2012, No. 2, s. 254. 
Systemy te wspierają również, przyjętą już za tradycyjną, strategię wyszukiwania różniącą się od odkrywania informacji tym, że użytkownik posiada dane, np. tytuł, nazwisko autora, słowa kluczowe, które wykorzystuje do odnalezienia dokumentu. Do grupy systemów wyszukiwania (search systems) zalicza się m.in. katalogi online i bazy danych ${ }^{10}$.

Pojęcie narzędzi odkrywania w literaturze stosuje się niekiedy zamiennie z terminem „systemy odkrywania”"11. Autor jednak postanowił je rozgraniczyć, ponieważ termin „narzędzie” oznacza urządzenie, przedmiot ułatwiający wykonanie jakiejś pracy ${ }^{12}$, w technologii informacyjnej ma węższe zastosowanie, zwane niekiedy funkcjonalnością lub funkcją. Systemy typu discovery składają się więc z narzędzi typu discovery, czyli funkcji za pomocą których użytkownicy odnajdują relewantne obiekty. Do funkcji takich należą:

- nawigacja fasetowa,

- charakterystyka przedmiotowa z użyciem metadanych w postaci linków,

- linki do szczegółowej prezentacji poszczególnych elementów opisu, np. spisu treści,

- nawigacja kontekstowa (np. zobacz również),

- wysyłanie e-mailem,

- ranking relewancji,

- historia aktywności (np. ostatnio przeglądane),

- narzędzia przeglądania zwartości tekstu,

- zapisywanie obiektów (abstraktów, tekstów),

- przeglądanie cytowanych źródeł.

Większość wymienionych narzędzi funkcjonuje w postaci nawigacji, tj. uruchamiana jest za pomocą kliknięcia (stuknięcia w przypadku urządzeń mobilnych) linku. W dalszej części artykułu zostaną szczegółowo omówione.

10 T. Sadeh, dz. cyt., s. 3.

11 Na przykład w artykułach: B. Thomsett-Scott, P. A. Reese, Academic Libraries and Discovery Tools. A Survey of the Literature, "College \& Undergraduate Libraries” 2012, 19, s. 127-128; J. C. Fagan, M. Mandernach, C. S. Nelson, J. R. Paulo, G. Saunders, Usability Test Results for a Discovery Tool in an Academic Library, „Information Technology and Libraries" 2012 March, s. 83-84.

12 Narzędzie. W: Słownik języka polskiego PWN [online] [dostęp 30 września 2017]. Dostępny w World Wide Web:http://sjp.pwn.pl/szukaj/narzędzie.html. 


\section{Systemy nawigacii i ich znaczenie}

Od początku powstania e-katalogów (OPAC-ów) zauważa się, że główną metodą wyszukiwania w nich informacji było formułowanie zapytań. Dlatego ten sposób odnajdywania wspierano zdecydowanie mocniej niż nawigację. Można go wręcz określić mianem tradycyjnego stylu wyszukiwania informacji. Nawigację projektuje się w celu pomocy użytkownikowi w przeglądaniu poszczególnych dziedzin, kategorii, podkategorii, opisów dokumentów, wyników wyszukiwania. Termin nawigacja obejmuje swym znaczeniem zespół aktywności użytkownika realizowanych za pomocą interfejsu aplikacji lub strony WWW w celu przemieszczenia się z aktualnego miejsca systemu do innego. Rezultatem zmiany lokalizacji może być „skok” do innego miejsca na tej samej stronie, wyświetlanie nowej strony, prezentacja zmienionej zawartości struktury nawigacji lub inne zmiany w wyświetlanej informacji ${ }^{13}$. Nawigacja to także linki, etykiety i inne elementy, które umożliwiają dostęp do stron oraz pomagają ludziom zachować poczucie orientacji podczas interakcji w serwisach WWW ${ }^{14}$.

Nawigacja należy do fundamentalnych elementów architektury informacji w serwisach internetowych obok systemu wyszukiwania, organizacji informacji i etykietowania ${ }^{15}$. Podstawowymi zadaniami nawigacji na stronach internetowych są:

- umożliwienie dostępu do informacji,

- pokazywanie lokalizacji na stronie,

- pokazywanie przedmiotu treści strony,

- odzwierciedlenie marki,

- wpływ na zaufanie użytkownika do jakości serwisu,

- oddziaływanie na rezultat ${ }^{16}$.

W Polsce badania na temat znajdowania drogi w katalogach bibliotek i bazach danych nie są popularne zarówno w kontekście zachowań informacyjnych, jak i projektowania oraz oceny użyteczności systemów informacyjnych.

13 ISO 9241-151: 2008(E), s. 16.

${ }^{14}$ J. Kalbach, Designing Web Navigation, Beijing 2007, s. 5.

15 L. Rosenfeld, P. Morville, J. Arango, Information Architecture. For the Web and Beyond, Fourth Edition, Beijing 2015, s. 24.

16 Tamże, s. 5. 
W systemach discovery, podobnie jak w całej globalnej pajęczynie, nawigacja jest elementem spajającym $w$ jedną sieć zasoby utrwalone w wielu formatach i rozmiarach. W przypadku systemów informacyjnych mechanizmem łączącym poszczególne obiekty są pola metadanych, dzięki którym możliwe jest przeglądanie podobnych dokumentów oraz ograniczanie listy wyników dzięki wskazaniu interesującej użytkownika cechy dokumentu.

Pojawienie się systemów typu discovery wpłynęło na zmianę sposobu interakcji i doświadczenia użytkownika (ang. userexperience), czyli na całokształt zachowań, emocje itp. pojawiające się podczas korzystania z systemu informacyjnego. Nowe opcje (funkcjonalności) spowodowały, że użytkownicy nie muszą już precyzyjnie określać cech poszukiwanego obiektu, tj. charakterystyk wyszukiwawczych, słów kluczowych itp., system może pomóc im odkryć relewantne dokumenty lub obiekty poprzez zestaw predefiniowanych metadanych, które użytkownicy wskażą jako priorytetowe z punktu widzenia własnych celów. W systemach informacyjnych o dokładnie ustalonej strukturze nawigacja nie jest tak często stosowaną metodą poszukiwania informacji, jak formułowanie zapytań w wyszukiwarce, a następnie przeglądanie listy wyników.

Nawigacja związana jest nie tylko z poruszaniem się pomiędzy stronami i tematami, ale przede wszystkim z określaniem własnej pozycji. Jej zadaniem jest ułatwianie zachowania poczucia orientacji poprzez oznaczenie miejsca, w którym użytkownik aktualnie się znajduje, gdzie już był, oraz wskazywanie kierunków, dokąd może pójść.

Strukturę nawigacji współtworzą wszystkie potencjalne ścieżki, którymi użytkownicy mogą poruszać się w systemie informacyjnym ${ }^{17}$. System ścieżek łączyć może ze sobą stronę domową i główne kategorie nawigacja globalna; podstrony lub wydzielone fragmenty treści należące do jednej kategorii (działu) - tzw. nawigacja lokalna, jak również podobne tematy - tzw. nawigacja kontekstowa.

Struktura nawigacji ponadto związana jest ściśle z organizacją informacji, podziałem zawartości na kategorie i podkategorie, które połączone są linkami ułatwiającymi użytkownikom przemieszczanie się w dowolnym kierunku. Dajmy na to od strony głównej do podstron zawierających treści szczegółowe, np. opis obiektu (nawigacja strukturalna), od tematu

17 PN-EN ISO 9241-151: 2008 (E), s. 17. 
szerszego do węższego (nawigacja lokalna), pomiędzy fragmentami informacji powiązanych ze sobą tematycznie (nawigacja kontekstowa). Na ilustracji 1 zaprezentowano model mapowania (przekształcania) struktury zawartości danego serwisu na system nawigacji. Poszczególne elementy struktury zawartości A, B, C oraz jej mniejsze fragmenty A1, B1 i C1 itd. przyporządkowane są węzłom (stronom) tworzącym system nawigacji 1, 2, 3 itd. Przyporządkowanie odbywa się wg trzech modeli relacji: jeden do jednego, wiele do jednego i jeden do wielu (zob. il. 1).

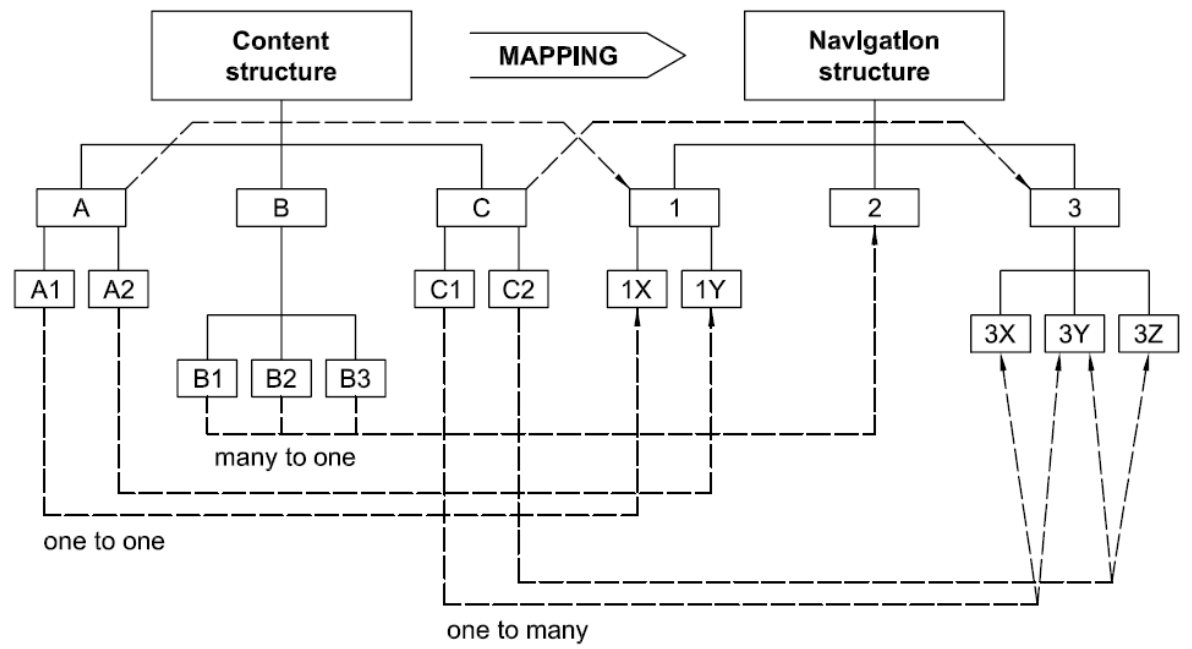

Ilustracja 1. Przykład mapowania elementów organizacji informacji na segmenty prezentacji

Źródło: PN-EN ISO 14915-2:2004 Ergonomia oprogramowania do multimedialnych interfejsów użytkownika - Część 2: Multimedialna nawigacja i kontrola.

W celu zachowania przejrzystości i logiczności prezentacji ścieżek nawigacyjnych dla użytkowników wykorzystać można koncepcję tzw. tropu informacji (ang. informationscent). Tropem informacji określa się właściwość odkrywania i użycia wskazówek, takich jak linki na stronach WWW, cytowania i przypisy bibliograficzne zawierające zwięzłą informację o zawartości (treści), która nie jest dostępna natychmiast, odgrywa on również istotną rolę w kierowaniu użytkowników do poszukiwanej informacji, a także zapewnia użytkownikom ogólne zrozumienie sensu 
całkowitej zawartości zbiorów ${ }^{18}$. Zgodnie z wynikami badań P. Pirollego im silniejszy trop informacji, tym zachowanie użytkownika prowadzi go dokładniej i bezpośrednio do celu ${ }^{19}$. Projektowanie ścieżek nawigacyjnych to, innymi słowy, naprowadzanie na trop informacji, który ułatwić może użytkownikom dotarcie do poszukiwanej treści.

W serwisach internetowych stosuje się wiele systemów nawigacji, które James Kalbach ${ }^{20}$ podzielił na trzy główne kategorie. Należą do nich:

1. Nawigacja strukturalna (ang. Structural navigation)

a) globalna

b) lokalna.

2. Nawigacja asocjacyjna (kojarzeniowa) (ang. Associative navigation)
a) kontekstowa
b) adaptacyjna - „użytkownicy, którzy kupili ten produkt kupili również"
c) szybkie linki
d) nawigacja w stopce.

3. Nawigacja użytkowa (ang. Utility navigation)

a) dodatkowa (zewnętrzna) (extra-site navigation)

b) narzędziowa (toolboxes)

c) linkowane logo (linked logos)

d) selektory kraju i języka (language and country selectors)

e) nawigacja wewnęrzna (internal page navigation) ${ }^{21}$.

Nie jest to jedyna typologia nawigacji ${ }^{22}$, należy jednak do najbardziej szczegółowych, uwzględnia bowiem różnorodne cele, jakim służyć ma wzajemne powiązanie stron i treści w jeden system.

W tej samej książce J. Kalbach wymienia pięć aspektów optymalnego systemu nawigacji:

1) wizualność - czy użytkownik widzi elementy nawigacji na stronie?

2) etykiety - czy etykiety są jasne i zrozumiałe?

18 P. Pirolli, Information Foraging Theory. Adaptive Interaction with Information, Oxford 2007, s. 68.

19 Tamże, s. 72.

20 J. Kalbach, dz. cyt., s. 86.

21 Tamże, s. 86-104.

22 Typologię nawigacji zaproponowali m.in. L. Rosenfeld i P. Morville w książce pt. Architektura informacji w serwisach internetowych, Gliwice 2003, s. 132. 
3) orientacja - czy użytkownicy gubią się, idąc wstecz lub naprzód?

4) znajdowalność - czy użytkownicy kończą sukcesem lokalizowanie informacji, której potrzebują?

5) skuteczność - czy użytkownicy wykonują zadanie wyszukiwawcze szybko i efektywnie? ${ }^{23}$

Użytkownicy, nawigując, szukają odpowiedzi na następujące pytania:

1) Gdzie jestem?

2) Gdzie mogę się udać?

3) Jak mogę się tam dostać?

4) W jaki sposób mogę wrócić do miejsca, gdzie już wcześniej byłem? ${ }^{24}$

Są one potwierdzeniem istotnej funkcji, jaką spełniają systemy nawigacji nie tylko w kontekście wskazywania drogi, ale przede wszystkim informowania użytkownika o aktualnej pozycji. Jennifer Flaming w książce pt. Web Navigation - prawdopodobnie pierwszej monografii poświęconej nawigacji w serwisach internetowych - wymienia kilka cech udanego systemu nawigacji: łatwość wyuczenia, konsekwencja, interaktywność, dostosowanie do kontekstu, efektywność oraz czytelność komunikatów ${ }^{25}$.

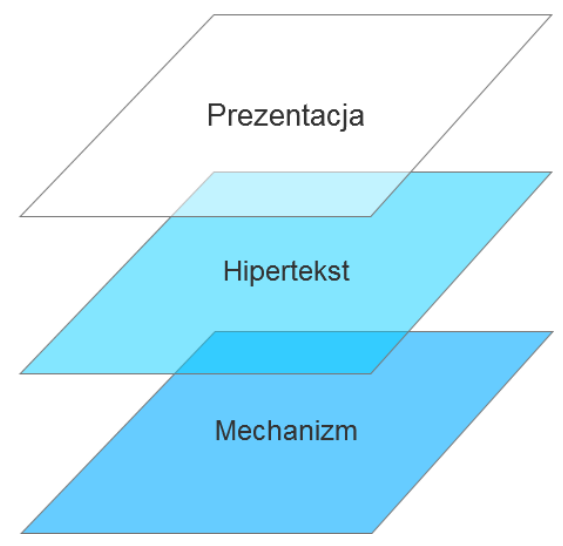

Ilustracja 2. Model struktury systemu nawigacji

Źródło: opracowanie własne.

${ }^{23}$ J. Kalbach, dz. cyt., s. 162.

24 J. Fleming, Web Navigation. Designing the User Experience, Beijing 1998, s. 5.

25 Tamże, s. 13-27. 
Dla potrzeb niniejszego artykułu w architekturze systemu nawigacji wyróżniono trzy warstwy: mechanizmu, hipertekstu i prezentacyjnej (il. 2). Mechanizmem nazwano linki lub zbiór linków działających w określony sposób i mających podobny wygląd ${ }^{26}$. W skład mechanizmu nawigacji wchodzi także układ elementów składowych systemu nawigacji (strony, metadane itp.) funkcjonujący w określonym kontekście, przeznaczony do realizacji konkretnego zadania, np. wspierania użytkownika w zawężaniu wyników wyszukiwania, wskazywania najkrótszej drogi do poszczególnych miejsc, łączenia ze sobą tematycznie powiązanych obiektów w celu ułatwienia użytkownikowi podążania za interesującym go tematem. Przykładowymi mechanizmami mogą być: nawigacja stronicowa, paski i zakładki nawigacyjne ${ }^{27}$.

Hipertekst w omawianej strukturze oznacza segment, który zawiera elementy składowe systemu nawigacji, a więc etykiety i węzły. Węzłami w tym przypadku mogą być pliki wg rodzaju formatu, np. pdf, html, doc, jpg, djvu itp. Do innego rodzaju węzłów należą samodzielne i identyfikowalne fragmenty stron lub podstron, np. akapity, podstrony, pliki, aplikacje, multimedia. Schematy hipertekstowych połączeń tworzą również metadane - przetwarzane informacje o dokumentach, obiektach, produktach.

Warstwa prezentacji zawiera elementy składające się na całościowy wygląd ekranu i interfejsu. Obejmuje ona etykiety, elementy graficzne (przyciski, „guziki”), tekst w postaci wyrazów, akapitów, punktorów.

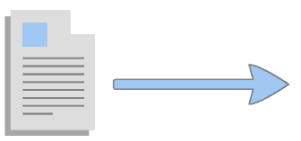

1

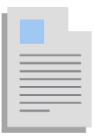

2

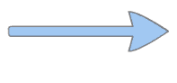

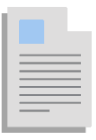

3

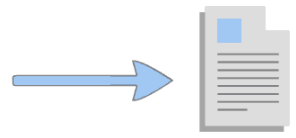

4

Ilustracja 3. Model nawigacji stronicowej, linearnej, łączącej podstrony w określonym porządku

Źródło: opracowanie własne.

${ }^{26}$ J. Kalbach, dz. cyt., s. 55.

27 Tamże, s. 69-70. 


\section{Nawigacia w wybranych systemach typu discovery}

Wśród analizowanych pod kątem prezentowania nawigacji systemów typu discovery znalazły się m.in.: Summon (University of Arizona Libraries), Primo (Politechnika Uniwersytetu Warmińsko-Mazurskiego w Olsztynie), Aquabrowser (Aargauer Bibliotheksnetz, ABN) ${ }^{28}$, Virtua/ Chamo (Biblioteka Główna Uniwersytetu Pedagogicznego w Krakowie), Encore (Biblioteka Narodowa w Warszawie), VuFind (University Chicago Library), Prolib Integra (Biblioteka Główna Uniwersytetu Przyrodniczo-Humanistycznego w Siedlcach).

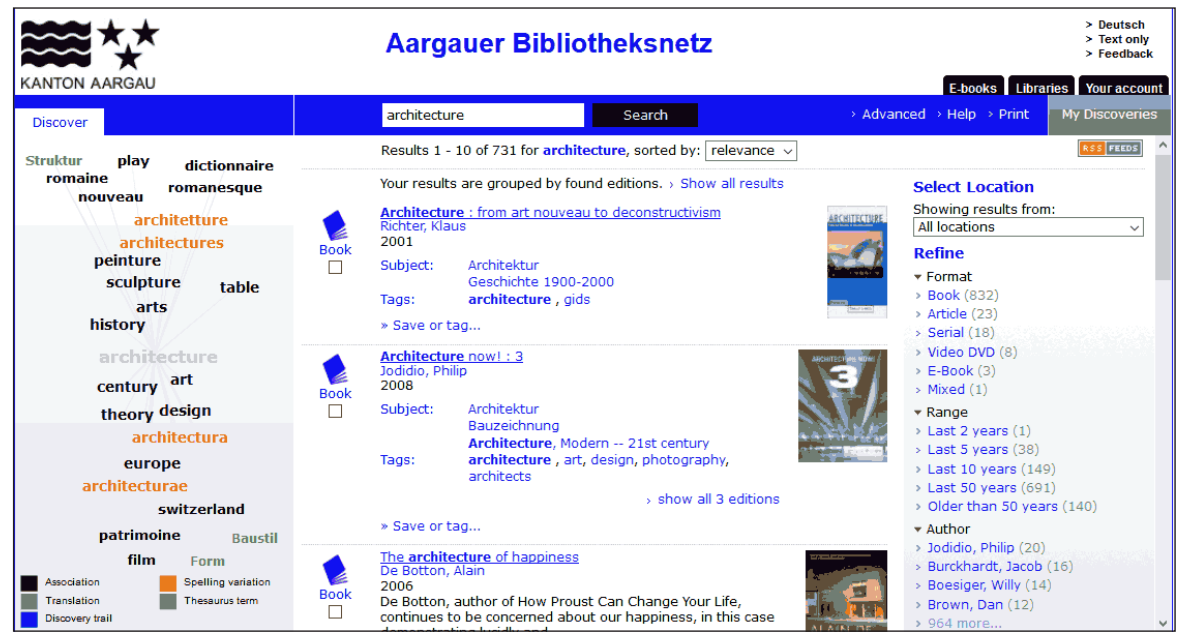

Ilustracja 4. Ekran katalogu Sieci Bibliotek w Aargau (Szwajcaria) w systemie discovery Aquabrowser (ProQuest)

Źródło: opracowanie własne.

W systemach typu discovery w zależności od rodzaju strony stosuje się różne mechanizmy nawigacji. Szczególne znaczenie mają dwa rodzaje stron, tj. wynikowa (ang. Search engine result page - SERP) oraz

${ }^{28}$ Sieć Bibliotek Kantonu Aargau, Szwajcaria (http://aargauer.aquabrowser.com/ [dostęp 30 września 2017]. 
tzw. strona produktu ${ }^{29}$ (strona docelowa, zawierająca szczegółowy opis książki lub artykułu, np. fotografię okładki, dane bibliograficzne, metadane). SERP w systemach odkrywania zawiera listę wyników i nawigację fasetową - filtry pozwalające zawęzić rezultat wyszukiwania bez konieczności wpisywania frazy wyszukiwawczej. Na stronach z opisem szczegółowym dokumentu umieszcza się linki kierujące do innych, podobnych dokumentów, pozwalających przejść do usługi zamawiania, rezerwacji, dodania do schowka itp.

\section{Prezentacja nawigacii}

Wraz z rozwojem World Wide Web oraz rozbudową serwisów internetowych pojawiła się potrzeba urozmaicania warstwy prezentacyjnej systemów nawigacji w celu ułatwienia użytkownikom ich wykorzystania i osiągnięcia własnych celów. Tak powstały m.in. mapy serwisów, indeksy stron itp., dzięki którym użytkownicy mogli dotrzeć na skróty do interesującego ich tematu. Problem prezentacji nawigacji pojawia się już na etapie projektowania koncepcji i prototypów wyglądu poszczególnych stron, np. systemu informacyjnego. Najczęściej spotkać się można z dwiema koncepcjami postrzegania systemów nawigacji w procesie projektowym, tj.:

- wysokopoziomową: polegającą na wizualizacji wzajemnych połączeń między stronami i podstronami (tzw. ogólna, ukazująca wzajemne połączenia strony głównej z podstronami niższego poziomu), prezentowaną np. w postaci hipertekstowej (il. 5a),

- niskopoziomową: prezentacja elementów systemu nawigacji (odnośników) na ekranie pojedynczej strony wraz z informacją o ich przeznaczeniu (kierunku) (il. 5b).

Podobne kryterium punktu odniesienia ogólnego podziału systemów nawigacji można zastosować do analizy wizualizacji elementów systemów nawigowania na ekranie. Wysokopoziomowa wizualizacja nawigacji występuje na stronach skupiających odnośniki do innych miejsc w systemie, np. strona wynikowa lub mapa serwisu. Niskopoziomowa zaś - na stronach zawierających skierowania do wybranych części serwisu. Sposoby prezentacji elementów systemów nawigacji zostaną omówione z uwzględ-

${ }^{29}$ J. Kalbach, dz. cyt., s. 110. 
nieniem ich położenia, tj. w którym miejscu w strukturze całego systemu znajduje się dana podstrona. Może to być jeden z czterech poziomów:

- wyszukiwarki

- wyników

- opisu dokumentu

- dokument (il. 6).
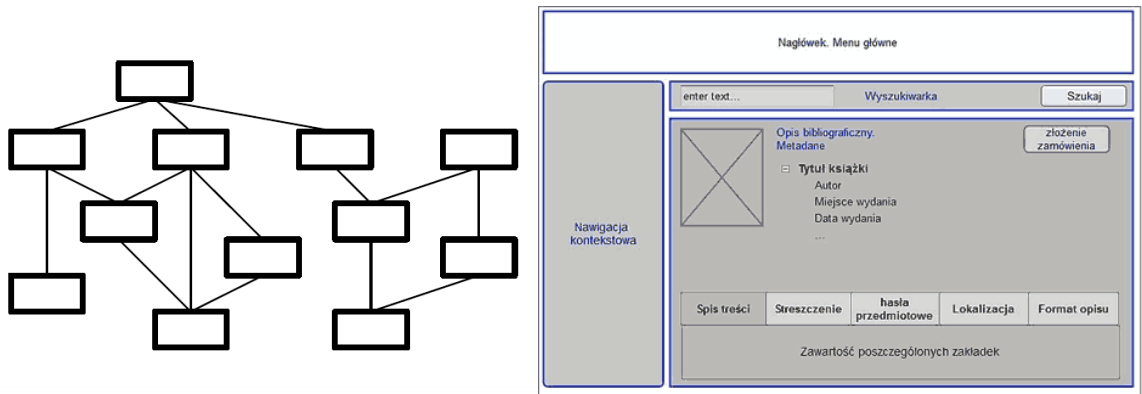

Ilustracja 5a i 5b. Wizualizacja nawigacji: wysokopoziomowa (z lewej) i niskopoziomowa (z prawej)

Źródło: z lewej PN-EN ISO 14915-2:2004, s. 5; z prawej: opracowanie własne.

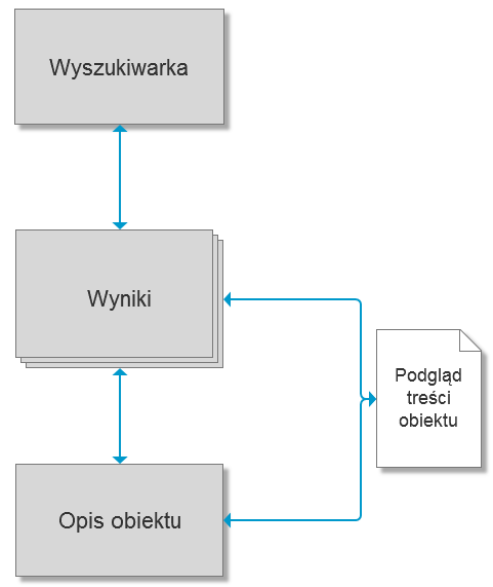

Ilustracja 6. Ścieżka użytkownika szukającego informacji składająca się z różnych rodzajów podstron Źródło: opracowanie własne. 

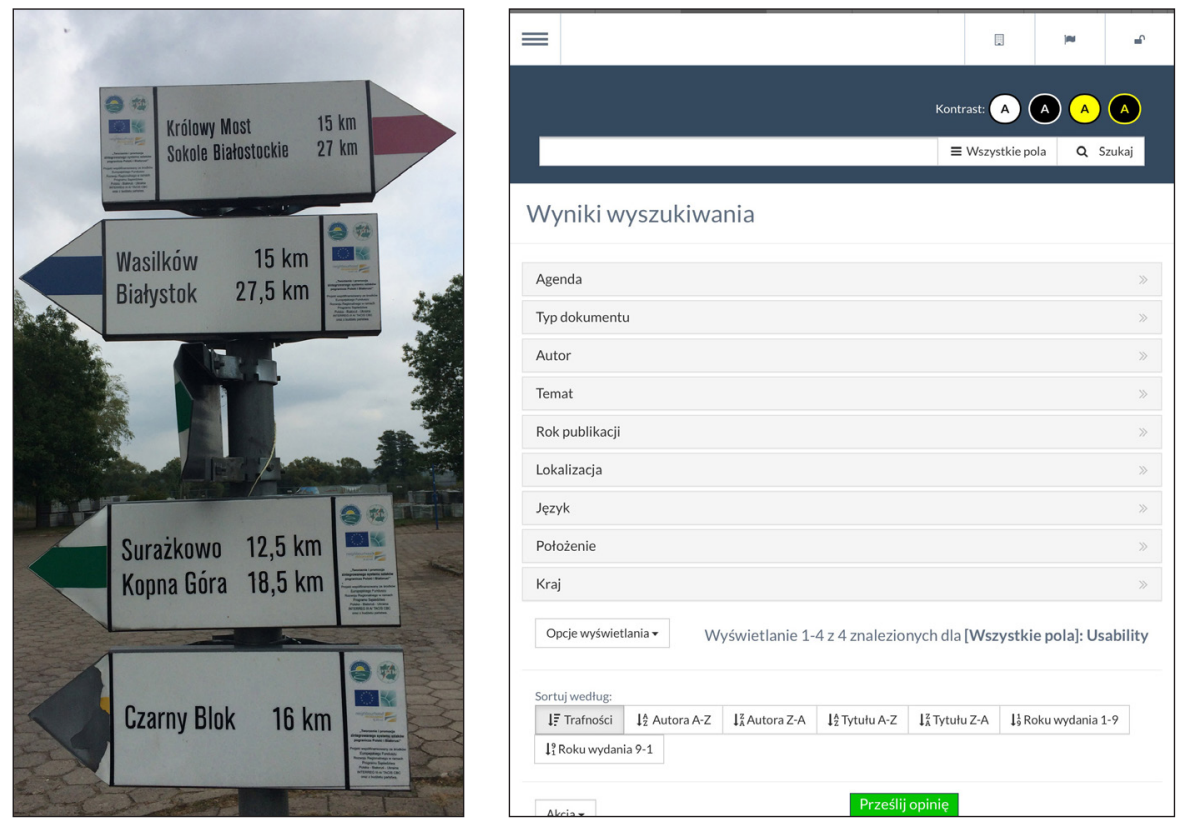

Ilustracja 7. Przykład wizualizacji szlaków turystycznych w Supraślu, woj. podlaskie

Ilustracja 8. Przykład ekranu interfejsu katalogu elektronicznego z systemem filtrów w postaci znaków kierunkowych w systemie Prolib. Biblioteka Uniwersytetu Przyrodniczo-Humanistycznego

Źródło: opracowanie własne.

Analiza interfejsów systemów discovery wskazuje, że ich projektanci mogli czerpać inspiracje do wizualizacji systemów nawigacji m.in. ze znaków i symboli znajdujących się w przestrzeni rzeczywistej (il. 7 i 8), takich jak znaki kierunkowe, orientacyjne, identyfikacyjne ${ }^{30}$. Jednak specyfika ekranu, na którym przeglądana jest zawartość, wymusza stosowanie rozwiązań charakterystycznych dla tego typu medium. Sposób prezentowania nawigacji na stronie WWW może przyjmować rozmaite

30 D. Gibson, The Wayfinding Handbooks. Information Design for Publc Places, New York 2009. 
formy, takie jakie tekst poziomy, tekst wertykalny, menu rozwijane (ang. drop-down), menu podrzędne, tekst z podpowiedzią, ikony lub grafika ${ }^{31}$.

\section{Nawigacja na stronie wyszukiwarki}

Formularz wyszukiwawczy zaliczany jest do tzw. stron funkcyjnych (ang. Functional pages), które nie zawierają dużej ilości elementów nawigacyjnych. W omawianych tu systemach informacyjnych najczęściej zawierały one pole hasłowe, odnośnik, za pomocą którego można wybrać zasoby, w jakich prowadzone będzie wyszukiwanie, np. bazy danych, katalog itp., oraz odnośniki do funkcji wyszukiwania zaawansowanego. Zdarzają się jednak systemy, w których - oprócz wymienionych wcześniej opcji wyszukiwarki - użytkownik może skorzystać z filtrów (Virtua/Chamo) (il. 9).

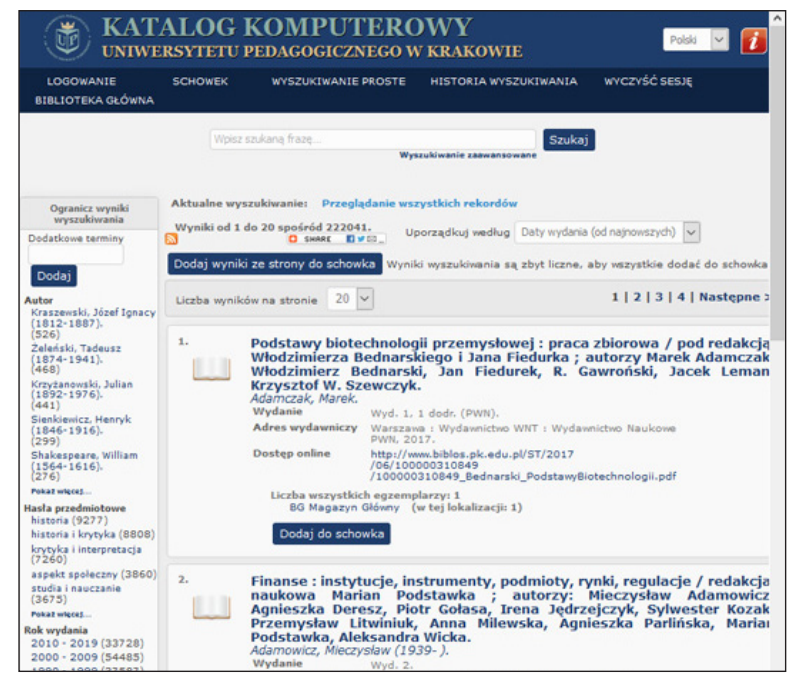

Ilustracja 9. Ekran katalogu Virtua/Chamo Biblioteki Głównej Uniwersytetu Pedagogicznego w Krakowie z pozycjami bibliograficznymi dostępnymi przed rozpoczęciem wyszukiwania

Źródło: opracowanie własne.

${ }^{31}$ E. Miller, Types of Website Navigation [online]. Thought Co. [dostęp 30 września 2017]. Dostępny w World Wide Web: https://www.thoughtco.com/types-of-website-navigation-1697495. 


\section{Nawigacja na stronie wynikowej}

Strona z wynikami, zwana m.in. stroną nawigacyjną ${ }^{32}$, zawiera listę linków (najczęściej autorów i tytułów publikacji) wyświetlanych w odpowiedzi na zapytanie użytkownika. Jednym z najnowszych trendów prezentacji wyników wyszukiwania jest wzorzec, tzw. pudełka bento (od nazwy pojemnika, tzw. bentobox, w którym sprzedaje się sushi na wynos) ${ }^{33}$. Podstawową cechą bentobox jest sortowanie i wyświetlanie wyników wyszukiwania według określonych kryteriów, np. rodzaju zasobów: księgozbioru, czasopism, dokumentów elektronicznych, baz danych itp. (il. 10). Prezentacje wyników według tego wzorca są dostarczane m.in. przez oprogramowania o nazwie LibGuides (Springshare LLC) w wersji 2.0 oraz VuFind (Vufind).

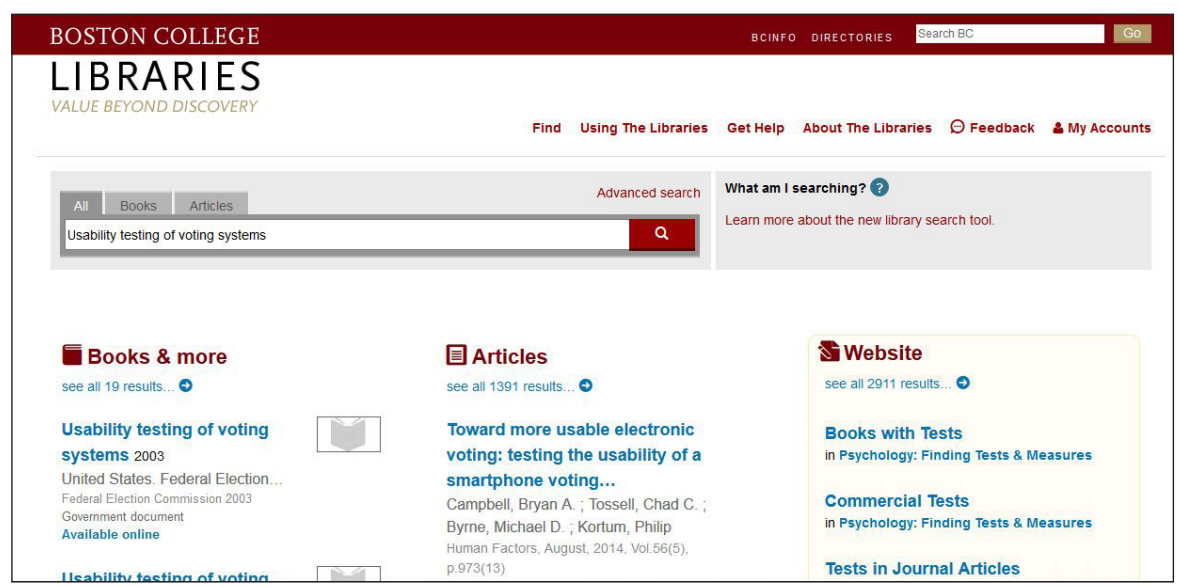

Ilustracja 10. Przykład prezentacji wyników wyszukiwania według modelu bentobox. Boston College Libraries

Źródło: opracowanie własne.

32 J. Kalbach, dz. cyt., s. 105.

${ }^{33}$ E. Singley, To Bento or Not to Bento - Displaying Search Results. W: Usablelibraries [online] January 4, 2016 [dostęp 30 września 2017]. Dostępny w World Wide Web: http:// emilysingley.net/usablelibraries/to-bento-or-not-to-bento-displaying-search-results/. 
Od 2006 r. strony wynikowe katalogów nowej generacji zostały wzbogacone o nowe, wspomniane już narzędzie wyszukiwania i przeglądania rezultatów - nawigację fasetową ${ }^{34}$. Zagadnieniu temu autor poświęcił osobną publikację ${ }^{35}$, dlatego $\mathrm{w}$ tym miejscu wystarczy wspomnieć, że to m.in. ten mechanizm wpłynął na zmianę sposobu wyszukiwania informacji, a w rezultacie również na jego nazwę - odkrywanie ${ }^{36}$. Umieszczenie nawigacji fasetowej na tym poziomie systemu typu $d i-$ scovery pozwala na zawężanie listy rezultatów do obiektów, które spełniają określoną cechę lub cechy. Wśród badanych interfejsów wszystkie miały mechanizm nawigacji fasetowej. Różnice w prezentacji zauważyć można w liczbie kategorii głównych (od 6 w Summon do 17 w Encore) ${ }^{37}$, lokalizacji mechanizmu z fasetami (z lewej strony - Summon, Primo, Encore, Prolib, Virtua/Chamo; z prawej - VuFind, Aquabrowser), liczbie elementów w poszczególnych opisach oraz zastosowanej kolorystyce. Ten ostatni czynnik jest istotny z punktu widzenia omawianej tu problematyki. We wszystkich przykładach interfejsów dominuje jasne tło. Tekst wyświetlany jest kontrastującym kolorem, m.in. czarnym (Encore, Summon, Aquabrowser) lub ciemnoszarym (Primo, Virtua/Chamo). Linki oznaczono kolorem niebieskim (Aquabrowser, Primo, Summon, ProlibIntegor), brązowym (Virtua/Chamo, ProlibIntegra). Wyjątkiem jest interfejs Encore Biblioteki Narodowej, w którym zarówno tekst, jak i linki są czarne (il. 12). Rozwiązanie to może obniżyć funkcjonalność strony i wpłynąć negatywnie na doświadczenia użytkowników. Norma zaleca, aby linki odróżniały się od tekstu statycznego ${ }^{38}$. Szata graficzna, a wraz z nią i kolorystyka jest elementem warstwy prezentacji, którą we współczesnych systemach informacyjnych można konfigurować według potrzeb biblioteki, np. poprzez ujednolicenie dla całej witryny. Priorytetem powinny tu być preferencje użytkowników, ułatwianie im zrozumie-

${ }^{34}$ K. La Barre, Faceted Navigation and Browsing Features in New OPACs. Robust Support for Scholarly Information Seeking?, „Knowledge Organization” 2007, 34 (2), s. 78.

35 S. Skórka, Fasety na nowo odkryte. Integrowanie systemów nawigacji i organizacji informacji, „Zagadnienia Informacji Naukowej” 2014, nr 2, s. 92-109.

36 A. Christensen, Next-generation Catalogues. What Do Users Think?, [w:] Catalogue 2.0. The Future of the Library Catalogue, edited by S. Chambers, London 2013, s. 9; T. Sadeh, dz. cyt., s. 5.

37 Porównanie liczby kategorii głównych przeprowadzono, wysyłając zapytanie „kapuscinski” (10 sierpnia 2017 r.).

38 PN-EN ISO 9241-151: 2008 (E), s. 20-21. 
nia, co jest tekstem, a co interaktywnym mechanizmem umożliwiającym m.in. dalsze wyszukiwanie.

Innym typem nawigacji stosowanej na stronach wynikowych jest tzw. nawigacja stronicowa, ułatwiająca przejście do następnych podstron z wynikami. Prezentowana jest najczęściej w postaci rzędu kolejnych cyfr - linków do kolejnych podstron (il. 11).

\begin{tabular}{ll|l|l}
\hline 1 & 2 & Następna » [2]
\end{tabular}

Ilustracja 11. Przykłady nawigacji stronicowej. Od góry: w systemie Prolib, u dołu VuFind

Źródło: opracowanie własne.

\begin{tabular}{|c|c|c|}
\hline Filtruj: & $\begin{array}{l}\text { D RSTązka | ZU10. } \\
\text { Dostępne w Magazyn Książek (1.697.915) plus } 1 \text { wiẹcej zobacz wszystko }\end{array}$ & \\
\hline \multirow{3}{*}{$\begin{array}{l}\square \text { Znaleziono w } \\
\square \text { Temat (1540) } \\
\square \text { Tytuł (151) } \\
\square \text { Autor (0) }\end{array}$} & & \\
\hline & & \\
\hline & $\begin{array}{l}\text { Rozwój przestrzenny i architektura Puszczykowa do } 1918 \\
\text { roku / Rafał Nadolny }\end{array}$ & W Zamów \\
\hline \multirow{2}{*}{$\begin{array}{l}- \text { Kolekcja } \\
\square \text { Bibliografia narodowa } \\
(915)\end{array}$} & Nadolny, Rafał. Autor & \multirow{3}{*}{$\begin{array}{l}\text { Dodatkowe operacje: } \\
\text { 尚 } \square B B B S \text { ts }\end{array}$} \\
\hline & 国 Artykuł | 2016. & \\
\hline $\begin{array}{l}\square \text { Czasopisma (463) } \\
\text { Artykuły z czasopism }\end{array}$ & $\rightarrow$ Przejdź do czasopisma zawierającego ten artykuł & \\
\hline \multicolumn{2}{|l|}{$\begin{array}{l}\text { Artykuły z czasopism } \\
\text { polskich (461) }\end{array}$} & \\
\hline \multirow{2}{*}{$\begin{array}{l}\square \text { Artykuły z gazet i } \\
\text { tygodników polskich (41) } \\
\square \text { Czytelnie (8) } \\
\text { więcej > }\end{array}$} & $\begin{array}{l}\text { Architektura obronna z obszaru powiatu szczycieńskiego. } \\
\text { Cz. 3, Gminy Wielbark i Rozogi / Grzegorz Swiderski } \\
\text { Świderski, Grzegorz. Autor }\end{array}$ & \multirow{2}{*}{$\begin{array}{l}\text { W Zamów } \\
\text { Dodatkowe operacje: } \\
\text { (nini } \square B G \text { BG th }\end{array}$} \\
\hline & 圆 Artykuł | 2016 & \\
\hline $\begin{array}{l}\text { - Autor } \\
\square \text { Natusiewicz Ryszard } \\
1927-2008 \text { (32) }\end{array}$ & $\rightarrow$ Przejdź do czasopisma zawierającego ten artykuł & \\
\hline \multirow{5}{*}{$\begin{array}{l}\square \text { Natusiewicz Marek (31) } \\
\square \text { Klimek Stanisław 1956- } \\
(26) \\
\square \text { Ilkosz Jerzy 1953- (21) } \\
\square \text { Krzyżanowski Lech } \\
\text { 1931-2017 (20) } \\
\text { więcej > }\end{array}$} & & \multirow{4}{*}{ 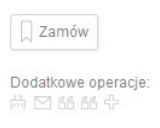 } \\
\hline & $\begin{array}{l}\text { Architektura gotyckich kościołów wiejskich pomiędzy Odrą a } \\
\text { Bobrem / Dominik Kwaśniak; Wojewódzki Urząd Ochrony } \\
\text { Zabytków, Zielona Góra }\end{array}$ & \\
\hline & Kwaśniak, Dominik. Autor & \\
\hline & 国 Artykuł | 2016. & \\
\hline & $\rightarrow$ Przejdź do czasopisma zawierającego ten artykuł & \\
\hline \multicolumn{3}{|c|}{ 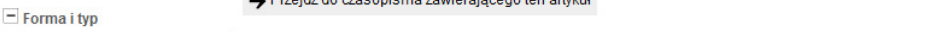 } \\
\hline \multicolumn{3}{|l|}{$\square$ Książki (847) } \\
\hline $\begin{array}{l}\square \text { Artykuły (538) } \\
\text { Druki ulotne (142) }\end{array}$ & $\begin{array}{l}\text { Secesyjna architektura Drezdenka / Zygmunt Marcinkowski } \\
\text { Marcinkowski, Zygmunt. Autor }\end{array}$ & Wamów \\
\hline
\end{tabular}

Ilustracja 12. Fragment ekranu strony wynikowej systemu Encore Biblioteki Narodowej (http://katalogi.bn.org.pl). Po lewej nawigacja fasetowa, w środkowej kolumnie wyniki, po prawej - nawigacja asocjacyjna typu toolbox

Źródło: opracowanie własne. 
Nowym typem nawigacji oferowanym na tym poziomie są miniaturowe odnośniki do narzędzi, np. wysyłanie e-mailem, zapis cytowania, zamówienie książki (Summon, Encore). Przeważnie wyświetlane są z prawej strony każdego opisu (il. 12). Tę odmianę nawigacji nazywa się pomocniczą (ang. toolbox).

\section{Nawigacja na stronach produktu}

Strony z opisem dokumentu (książki, czasopisma, dokumentu cyfrowego itp.), zwane również stronami produktu ${ }^{39}$, prezentują rekord dokumentu w postaci szczegółowych cech danego przedmiotu, które szczegółowo go identyfikują, umożliwiając jednocześnie podjęcie dalszych działań. Strona z rekordem zwykle zawiera: tytuł dokumentu, niekiedy w postaci dużego tekstu umieszczonego pod nagłówkiem strony (Virtua/Chamo, VuFind, Prolib), zdjęcia obiektu, opis, informacje o dostępności i dostawie, dalsze szczegóły, linki do produktów powiązanych itp. Elementy opisu ułożone są $\mathrm{w}$ formie listy - jeden pod drugim. Każdy element poprzedza nazwa pola, np. autor, współtwórcy, temat. Wyjątkiem jest opis w systemie Encore, podzielony na trzy sektory: opis skrócony - zawierający najważniejsze informacje identyfikujące dokument oraz wskazówkę o dostępności w bibliotece; pozycje - egzemplarze i ich sygnatury; więcej szczegółów - lista metadanych: adres wydawniczy, opis fizyczny, temat, ISBN itp. Prezentacyjna warstwa interfejsu Encore, jak wspomniano wcześniej, może być dla użytkowników niefunkcjonalna - zarówno linki, jak i tekst wyglądają identycznie, sformatowano je tym samym (czarnym) kolorem. W większości badanych interfejsów nazwy pól metadanych wyświetlane są innym kolorem (np. czarnym lub szarym) niż ich wartości (niebieskim) (il. 13).

Nawigacja na tym poziomie kieruje do różnych odmian opisów (Virtua/Chamo, VuFind), innych pozycji tego samego autora, wydawcy, publikacji o tej samej tematyce (Encore, VuFind, Primo). W omawianych tu przykładach systemów discovery szata graficzna nawiązywała do strony wynikowej, tj. zastosowano takie samy barwy oraz kroje fontów. Wyjątkiem jest Biblioteka Uniwersytetu w Arizonie, której strony wynikowe pobierane są z innego systemu - elektronicznego katalogu WebPac Pro

39 J. Kalbach, dz. cyt., s. 109-110. 


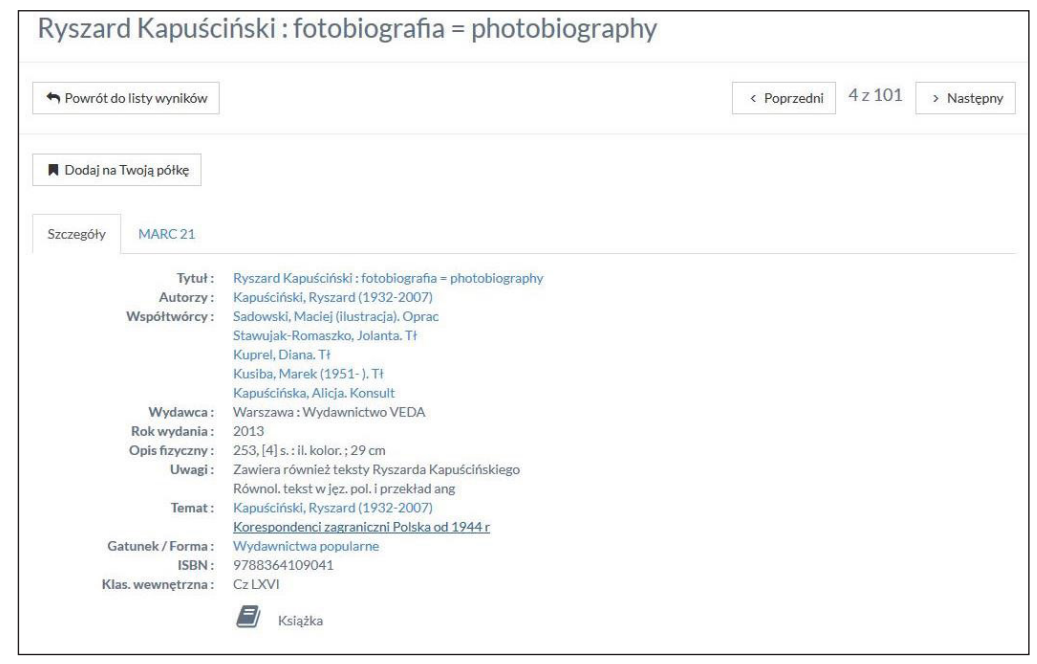

Ilustracja 13. Fragment interfejsu strony z opisem książki w Prolib Integro (BG Uniwersytetu Przyrodniczo-Humanistycznego w Siedlcach). Etykiety prezentowane są odcieniem szarości, linki - niebieskim

Źródło: opracowanie własne.

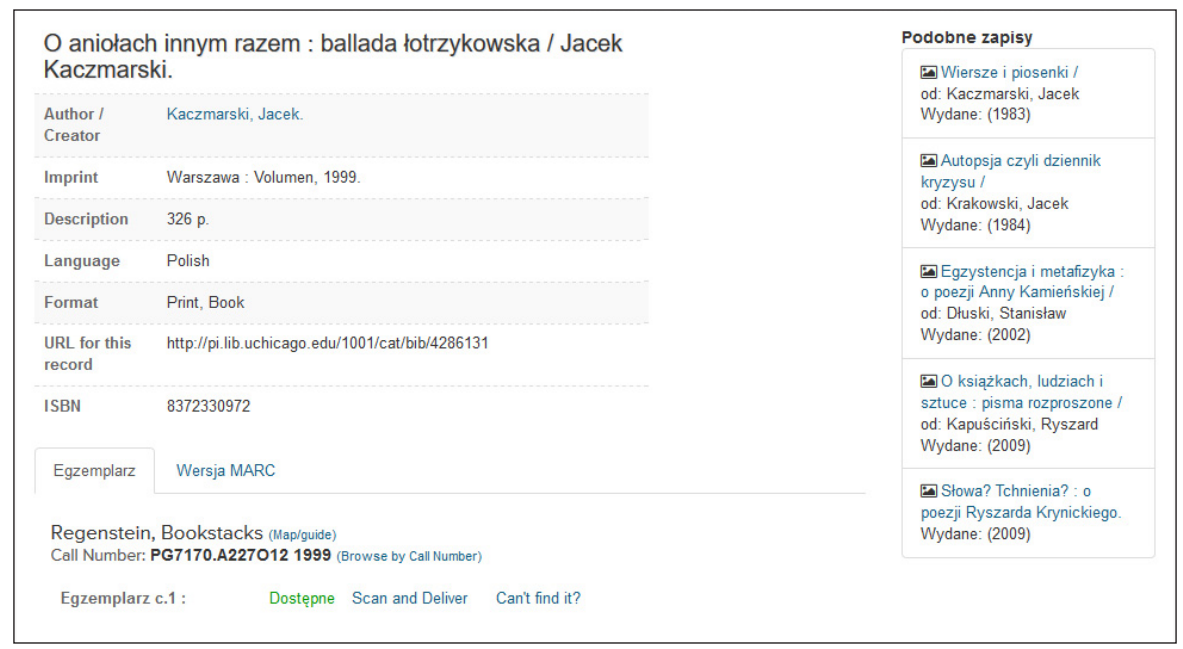

Ilustracja 14. Fragment ekranu strony z opisem z interfejsu VuFind University of Chicago Library (https://catalog.lib.uchicago.edu/. Z prawej strony widoczna jest nawigacja adaptacyjna

Źródło: opracowanie własne. 
(Innovative), co nietrudno zauważyć z powodu nieco innej szaty graficznej, m.in.: font oraz jego styl.

Na podstronach z rekordami pojawiły się nieopisywane wcześniej odmiany nawigacji, m.in. tzw. nawigacja dodatkowa (linki do serwisów społecznościowych i innych witryn zewnętrznych) w postaci minipiktogramów logotypów (np. Encore, Aquabrowser) oraz nawigacja adaptacyjna - $\mathrm{w}$ formie listy powiązanych tematycznie publikacji (VuFind) (il. 14).

W tabeli 1 przedstawiono rodzaje nawigacji zauważone w wybranych systemach discovery. Wszystkie z badanych systemów miały nawigację stronicową, ułatwiającą przeglądanie kolejnych stron z wynikami oraz nawigację krokową - pozwalającą na przejście do następnej/poprzedniej strony. Przeważnie była ona prezentowana w postaci linków tekstowych (Poprzedni, Następny, Wyniki wyszukiwania). Strony z opisami zawierały również nawigację dodatkową, pozwalającą wykonać szereg zadań, takich jak drukowanie, cytowanie w wybranym formacie, dodanie do schowka, udostępnienie linku, wysłanie e-mailem itp. Zauważalna była różnorodność w jej prezentacji: przyciski (Virta/Chamo), menu dynamiczne (Primo), tekst (Prolib, VuFind), paski narzędzi (Encore, Summons).

Niektóre z systemów nawigacji występowały tylko w pojedynczych przypadkach, np. wyświetlanie terminów towarzyszących liście wyników (słownika kontrolowanego) w interfejsie Aquabrowser (il. 4). Zaprezentowano je w atrakcyjnie wyglądającej „chmurze”, z zastosowaniem odrębnej kolorystyki dla terminów tłumaczonych, tezaurusowych, powiązanych relacjami z wyszukiwanym tematem, będących innym wariantem wymowy (np. architecture - architecturae). Interfejs ten zaprojektowano na podstawie doświadczeń użytkowników, zawiera on trzy typy narzędzi wyszukiwania informacji, za pomocą których realizują oni swoje potrzeby, tj. wyszukiwanie, odkrywanie i oczyszczanie (ang. search, discover, refine) ${ }^{40}$.

Inną, ciekawą i oryginalną opcję nawigacyjną oferowała Biblioteka Uniwersytetu w Chicago (VuFind) - odnośniki do powiązanych kontekstowo tekstów. W prawej kolumnie strony z opisem system wyświetla podpowiedzi z podobnymi pracami (il. 14). Ten typ nawigacji, zwany adaptacyjnym, jest od wielu lat stosowany w sklepach internetowych,

40 T. Ekkel, J. Kaizer, AquaBrowser. Search and Information Discovery for Libraries, „Information Services \& Use”, 2007 (27), s. 79-80. 


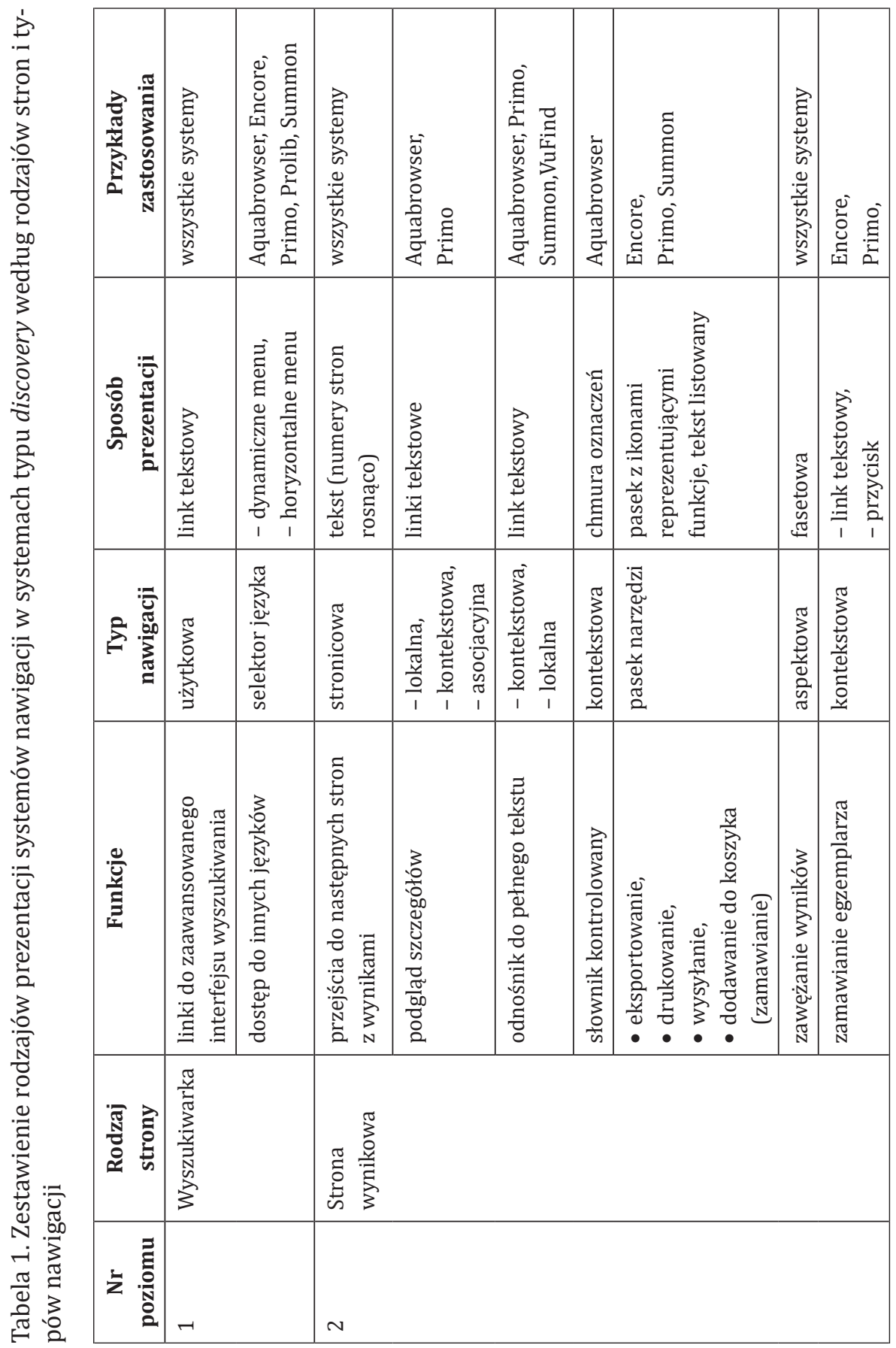




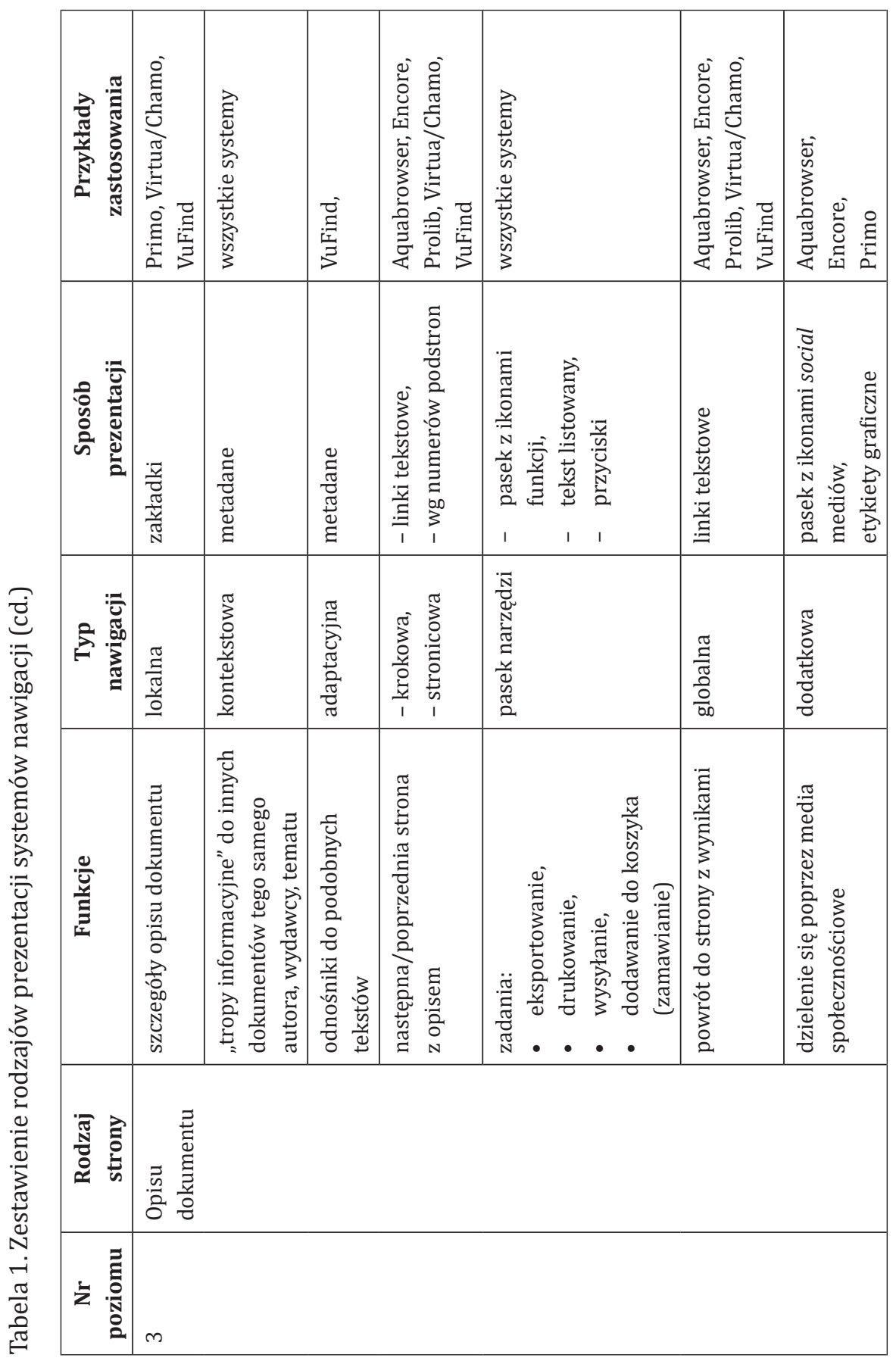

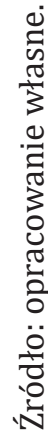


opatrzonych np. etykietą „Klienci, których interesował ten produkt, oglądali też..." ${ }^{41}$.

\section{Podsumowanie}

Zaważono, że systemom nawigacji w zależności od typu strony, na której występują, przypisuje się określone zadnia. Na stronach wynikowych dominują odnośniki i narzędzia służące zachowaniu rezultatów wyszukiwania w celu ich dalszego użycia. Z kolei zadaniem nawigacji na stronach z opisami jest przybliżenie szczegółów obiektu oraz umożliwienie jego zamówienia.

Formy prezentowania systemów nawigacji w serwisach typu discovery nie odbiegają od standardów stron sklepów internetowych, które ze względów ekonomicznych jako pierwsze implementują nowe technologie oraz najnowsze trendy w swoich witrynach. Specyfika zasobów bibliotecznych oraz skromniejsze środki finansowe nie pozwalają na równoczesne wprowadzanie nowinek z dziedziny web designu do systemów informacyjnych. Mimo to zastosowane w omawianych interfejsach sposoby prezentowania nawigacji mogą być czytelne i zrozumiałe dla użytkowników. Ich wizualizacja jest różnorodna w zależności od typu strony w systemie. Najwięcej rodzajów nawigacji, a co za tym idzie form prezentacji, zauważa się na stronach wynikowych i opisu rekordu dokumentu.

Zagadnienia związane z systemami nawigacji w serwisach typu discovery nie są w Polsce zbyt popularne, co przekłada się na ich użyteczność. Często bowiem projektanci i programiści liczą się z opinią bibliotekarzy, a nie odbiorców. Dlatego nierzadko w interfejsach systemów informacyjnych umieszcza się terminy i etykiety specjalistyczne, niezrozumiałe dla sporej grupy odbiorców. Badania z udziałem użytkowników nie-bibliotekarzy nad użytecznością i wykorzystywaniem systemów odkrywania informacji najprawdopodobniej wpłynęłyby na podniesienie ich poziomu funkcjonalności, a tym samym zwiększenie ilości usatysfakcjonowanych użytkowników. Zbadanie m.in. wpływu, jaki wywiera lokalizacja oraz

${ }^{41} \mathrm{~Np} . \mathrm{w}$ empik.com, Internetowy sklep rowerowy [www.rowerowy.biz, dostęp 30 września 2017]. 
forma prezentacji linków, a także odpowiedź na pytanie, jakich modyfikacji wymagają funkcje nawigacji umieszczone na stronach systemu, pozwoliłyby wskazać dalszy kierunek rozwoju systemów informacji naukowej.

\section{Bibliografia}

Breeding Marshall, The Future of Library Resource Discovery. A White Paper Commissioned by the NISO Discovery to Delivery (D2D) Topic Committee [online]. Baltimore: NISO, 2015, 53 s. [dostęp 30 września 2017]. Dostępny w World Wide Web: http://www.niso.org/apps/group_public/download. php/14487/future_library_resource_discovery.pdf, s. 3-4.

Christensen Anne, Next-generation Catalogues. What Do Users Think?, [w:] Catalogue 2.0. The Future of the Library Catalogue, edited by Sally Chambers, London 2013, s. 1-15.

E-Discovery Tools and Applications in Modern Libraries, ed. by Egbert de Smet, Sangeeta Dhamdhere, Hershey 2016.

Ekkel Taco, Kaizer Jasper, Aqua Browser. Search and Information Discovery for Libraries, „Information Services \& Use” 2007 (27), s. 79-83.

Fagan Jody C., Mandernach Meris, Nelson Carl S., Paulo Jonathan R., Saunders Grover, Usability Test Results for a Discovery Tool in an Academic Library, „Information Technology and Libraries” 2012 March, s. 83-112.

Fleming Jenifer, Web Navigation. Designing the User Experience, Beijing 1998.

Hofmann Melissa A., Yang Sharon Q., "Discovering" What's Changed. A Revisit of the OPACs of 260 Academic Libraries, „Library Hi Tech” vol. 30: 2012, No. 2, s. 253-274.

Kalbach Jim, Designing Web Navigation, Beijing 2007.

La Barre Kathryn, Faceted Navigation and Browsing Features in New OPACs. Robust Support for Scholarly Information Seeking?, „Knowledge Organization” 2007, 34(2), s. 78-90.

Narzędzie. W: Słownik języka polskiego PWN [online] [dostęp 30 września 2017]. Dostępny w World Wide Web: http://sjp.pwn.pl/szukaj/narzędzie.html. Pirolli Peter, Information Foraging Theory. Adaptive Interaction with Information, Oxford 2007.

PN-EN ISO 14915-2:2004 Ergonomia oprogramowania do multimedialnych interfejsów użytkownika - Część 2: Multimedialna nawigacja i kontrola. 
PN-EN ISO 9241-151:2008 Ergonomia interakcji człowieka i systemu - Część 151: Wytyczne dotyczace interfejsów użytkownika stosowanych w sieci World Wide Web.

Rosenfeld Louis, Morville Peter, Arango Jorge, Information Architecture. For the Web and Beyond, Fourth Edition, Beijing 2015.

Sadeh Tamar, From Search to Discovery [online]. IFLA Library [dostęp 30 września 2017]. Dostępny w World Wide Web: http://library.ifla.org/id/eprint/104, s. $1-17$.

Singley Emily, To Bento or Not to Bento - Displaying Search Results. W: Usable Libraries [online] January 4, 2016 [dostęp 30 września 2017]. Dostępny w World Wide Web: http://emilysingley.net/usablelibraries/to-bento-ornot-to-bento-displaying-search-results/.

Skórka Stanisław, Fasety na nowo odkryte. Integrowanie systemów nawigacji i organizacji informacji, „Zagadnienia Informacji Naukowej” 2014, nr 2, s. 92-109.

Thomsett-Scott Beth, Reese Patricia E., Academic Libraries and Discovery Tools. A Survey of the Literature, „College \& Undergraduate Libraries” 2012, 19 , s. 123-143.

Wang Yongming, MiJia, Searchability and Discoverability of Library. Resources.

Federated Search and Beyond, „College \& Undergraduate Libraries” 2012, 19: 2-4, s. 229-245.

Ware Colin, Information Visualization: Perception for Design, 2nd Edition, Amsterdam 2004.

\section{Visualisation of Navigation Systems in Discovery Services}

ABSTRACT: Next generation Integrated Library Systems (NGILS) also known as discovery and delivery systems or search and discovery systems, are claimed to be significant innovation in information searching field as well as its visualisation methods. One of the explanation is extended retrieval scope including e-documents in data bases and repositories. Navigation systems have a significant meaning in properly functionality of NGILS. Navigation provide ways to achievement of users' goals. Main aim of the article is a comparative analysis of navigation systems in selected NGILS: VuFind (open source), Primo ExLibris, Summon ProQuest, Encore Innovative Interfaces, ProlibIntegro, Virtua/Chamo. 
The visualisation layer of NGILS navigation mechanisms was also discussed. Optimal visualisation of interfaces and navigation assist users in making decision process, and in link selection.

KEYWORDS: information systems, next generation library system, discovery services, navigation, visualisation of navigation systems. 